\title{
Analisis Kebutuhan Media Literasi Berbasis Digital pada Anak Usia Dini
}

\author{
Syarif Hidayatullah ${ }^{\circledR}{ }^{\bowtie}$, Syihabuddin ${ }^{2}$, Vismaia Damayanti ${ }^{3}$ \\ Pendidikan Bahasa Indonesia, Universitas Pendidikan Indonesia $(1,2,3)$ \\ Pendidikan Bahasa dan Sastra Indonesia, Universitas Muhammadiyah Prof. Dr. Hamka(1) \\ DOI: $10.31004 /$ obsesi.v6i3.1183
}

\begin{abstract}
Abstrak
Masalah literasi yang rendah di Indonesia telah menarik banyak perhatian peneliti Indonesia. Namun belum ada upaya untuk mengatasi permasalahan ini dari akarnnya, yaitu anak usia dini. Guru dan orang tua pada jenjang ini selalu berharap anaknya dapat berkembang opitimal terutama dalam literasi sehingga mereka dapat sukses dalam belajar saat sekolah. Akan tetapi, belum ada media yang membuat usaha guru dan orang tua sejalan. Untuk itu penelitian ini berupaya menganalisis kebutuhan guru dan orang tua untuk kegiatan literasi anak di sekolah dan di rumah dalam bentuk media literasi berbasis digital. Metode yang digunakan adalah dengan angket dan wawancara yang dilakukan kepada 28 guru TK dan 15 orang tua murid. Hasil penelitian ini menunjukkan bahwa guru dan orang tua berharap bahwa media literasi tersebut dapat dimainkan lintas gender, berisi aktivitas bernyanyi, menggambar, bercerita, dan bermain. Dengan hasil ini, diharapkan ada media digital yang memuat aktivitas tersebut sehingga dapat dimanfaatkan untuk kegiatan literasi pada anak usia dini.
\end{abstract}

Kata Kunci: analisis kebutuhan; literasi; literasi emergen; pendidikan anak usia dini.

\begin{abstract}
The problem of low literacy in Indonesia has attracted a lot of attention from Indonesian researchers. However, there has been no effort to solve this problem from its roots, namely early childhood. Teachers and parents at this level always hope that their children can develop optimally, especially in literacy so that they can be successful in learning at school. However, there is no media that brings the efforts of teachers and parents together. For this reason, this study seeks to analyze the needs of teachers and parents for children's literacy activities at school and at home in the form of digital-based literacy media. The method used was a questionnaire and interviews conducted with 28 kindergarten teachers and 15 parents. The results of this study indicate that teachers and parents hope that literacy media can be played across genders, containing singing, drawing, storytelling, and playing activities. With these results, it is hoped that there will be digital media containing these activities so that they can be used for literacy activities in early childhood.
\end{abstract}

Keywords: needs analysis; literacy; emergent literacy; early childhood education programs.

Copyright (c) 2021 Syarif Hidayatullah, et al.

$\bowtie$ Corresponding author :

Email Address : syarifbahagia@upi.edu (Bandung, Indonesia)

Received 8 March 2021, Accepted 4 May 2021, Published 27 July 2021 


\section{PENDAHULUAN}

Kemampuan literasi awal (literasi emergen) merupakan kemampuan penting yang harus dicapai anak sebelum ia masuk ke dalam fase sekolah. Hal ini karena kemampuan ini akan sangat mempengaruhi kesuksesan belajar anak saat sekolah (Fajriyah, 2018). Namun, di Indonesia kesadaran mengenai literasi masih rendah. Hal ini ditandai dengan hasil penelitian yang disampaikan oleh Central Connecticut State University yang melakukan pemeringkatan literasi di dunia. Dalam hasil penelitian tersebut, Indonesia berada pada urutan 60 dari 61 negara (Miller \& McKenna, 2016). Itu menunjukkan bahwa tingkat literasi Indonesia masih sangat rendah.

Persoalan literasi di Indonesia memang dilatarbelakangi oleh banyak faktor. Salah satu faktornya adalah lingkungan keluarga. Hasil penelitian menyampaikan bahwa latar belakang ekonomi memberikan faktor yang signifikan pada kebiasaan literasi di tengah keluarga. Hal ini membuat anak yang berada pada tingkat ekonomi rendah jarang terpapar pada kegiatan literasi, sebaliknya dengan tingkat ekonomi lebih tinggi maka anak lebih banyak terpapar kegiatan literasi. Minimnya akses literasi membuat anak yang hidup pada keluarga dengan tingkat ekonomi rendah kesulitan untuk mengembangkan kemampuan literasinya (Astuti, 2015). Dalam arti lain, bahwa kemampuan literasi dipengaruhi oleh contoh yang ada di sekitar anak. Semakin sering anak mendapatkan contoh dalam berliterasi, maka semakin tinggi ia memiliki kemampuan literasi (Inten, 2017). Contoh tersebut sangat jarang ditemui dalam lingkungan keluarga dengan tingkat ekonomi rendah.

Selain faktor tersebut, faktor lainnya adalah ketidaksesuaian buku bagi sasaran pembacanya. Buku merupakan faktor penting dalam kegiatan literasi. Namun, jika buku tidak sesuai dengan kebutuhan pembacanya maka akan berdampak negatif bagi kegiatan literasi itu sendiri. Hasil penelitian menunjukkan banyak sumber buku yang tidak sesuai dengan bahan bacaan untuk literasi emergen (Sidik, 2020). Hal tersebut ditandai dengan fisik buku yang memuat terlalu banyak informasi yang itu membuat buku tersebut tidak layak untuk pembaca pemula. Hal ini sekaligus tidak sesuai dengan panduan parameter buku yang sesuai untuk kegiatan pramembaca (Kemendikbud, 2018).

Usaha untuk meningkatkan literasi telah banyak dilakukan oleh guru, misalnya dengan melakukan fasilitasi kegiatan literasi melalui pojok bacaan yang hasilnya cukup signifikan dalam meningkatkan literasi anak (Handayani, 2019). Usaha lain misalnya dengan melakukan stimulus literasi dengan kegiatan bermain yang juga memberikan dampak positif (Hewi, 2020). Namun demikian, kegiatan literasi tidak hanya berjalan satu arah. Artinya, jika literasi hanya dirayakan pada ruang-ruang pendidikan formal di TK sementara di rumah para anak tidak mendapatkan haknya dalam berliterasi, maka anak kemungkinan akan kesulitan untuk meningkatkan kemampuan berliterasinya ( $\mathrm{Li}, \mathrm{Nan}, \mathrm{Xu}, \& \mathrm{Li}, 2020)$. Oleh karena itu perlu sarana yang memfasilitasi antara kegiatan literasi di sekolah dan di rumah. Namun demikian, sampai saat ini tidak ada sarana yang tepat yang mampu memberikan kontribusi pada pencapaian anak dalam berliterasi secara bersama-sama baik di sekolah maupun di rumah.

Penelitian ini berupaya untuk mencari solusi dari permasalahan literasi dengan memanfaatkan aplikasi digital yang dapat diakses oleh guru dan orang tua untuk memberikan pengayaan literasi di sekolah dan dirumah. Untuk merumuskan konsep aplikasi digital yang relevan, maka dalam penelitian ini dilakukan analisis kebutuhan yang diharapkan oleh guru dan orang tua dalam memanfaatkan aplikasi digital tersebut.

\section{METODOLOGI}

Penelitian ini merupakan bagian dari penelitian dan pengembangan yang diadaptasi dari konsep research an development (Borg \& Gall, 1983) yang diawali dengan riset pendahuluan. Dalam konteks penelitian ini, dilakukan analisis kebutuhan dalam mengembangkan produk, yaitu media literasi berbasis digital. 
Populasi yang digunakan dalam penelitian ini adalah 28 guru TK dan 15 orang tua murid dengan teknik pengambilan data secara acak. Instrumen yang digunakan dalam penelitian ini berupa angket dan wawancara. Data yang diperoleh kemudian dideskripsikan untuk kemudian ditarik kesimpulan.

\section{HASIL DAN PEMBAHASAN}

Hasil angket dan wawancara merumuskan bahwa media digital harus mampu memberikan aktivitas literasi yang dapat diakses baik di sekolah maupun di rumah. Aktivitas literasi yang ada di dalam aplikasi digital tersebut dapat dimainkan secara kolektif maupun individu sehingga memunculkan ruang komunikasi di dalam proses penggunaan aplikasi. Secara singkat, rumusan kebutuhan media literasi berbasis digital tersebut pada tabel 1.

Tabel 1. Rumusan Kebutuhan Media Literasi Berbasis Digital

\begin{tabular}{ll}
\hline \multicolumn{1}{c}{ Kebutuhan } & \multicolumn{1}{c}{ Keterangan } \\
\hline $\begin{array}{l}\text { Permainan Lintas } \\
\text { Gender }\end{array}$ & $\begin{array}{l}\text { Grafis menunjukkan warna-warna yang cerah dengan desain dan warna } \\
\text { yang tidak mencerminkan identitas gender tertentu sehingga tidak hanya } \\
\text { dimainkan oleh anak laki-laki atau perempuan. }\end{array}$ \\
\hline $\begin{array}{l}\text { Memuat aktivitas } \\
\text { bernyanyi }\end{array}$ & $\begin{array}{l}\text { Kegiatan bernyanyi merupakan bagian dari fonologi bahasa yang dapat } \\
\text { dilakukan sebagai aktivitas individu maupun kolektif }\end{array}$ \\
\hline $\begin{array}{l}\text { Memuat aktivitas } \\
\text { menggambar }\end{array}$ & $\begin{array}{l}\text { Kegiatan menggambar memberikan di aplikasi memberikan kesan } \\
\text { interaktif antara pengguna dengan aplikasi digital sekaligus sebagai } \\
\text { penguatan literasi dari pemahaman kata atau klausa yang diberikan. }\end{array}$ \\
\hline $\begin{array}{l}\text { Memuat aktivitas } \\
\text { bercerita }\end{array}$ & $\begin{array}{l}\text { Kegiatan bercerita dapat berupa gambar dengan satu dua kalimat yang } \\
\text { diperkenalkan kepada anak yang menanamkan karakter atau } \\
\text { kepribadian tertentu. }\end{array}$ \\
\hline $\begin{array}{l}\text { Memuat aktivitas } \\
\text { bermain }\end{array}$ & $\begin{array}{l}\text { Kegiatan bermain menyusun gambar acak atau urutan huruf akan } \\
\text { membuat anak semakin mengenal kata atau huruf tertentu. }\end{array}$ \\
\hline
\end{tabular}

\section{Permainan Lintas Gender}

Kebutuhan tentang media literasi tidak spesifik dibutuhkan oleh gender tertentu. Hal ini karena persoalan literasi tidak hanya dialami oleh anak laki-laki, namun juga anak perempuan. Meskipun dalam data penelitian bahwa anak laki-laki cenderung mengalami kemunduran dalam litarasi dibandingkan anak perempuan, namun bukan berarti perlu perbedaan di antara keduanya (Prioletta \& Pyle, 2017). Selama ini permainan tertentu sering dianggap terlalu lelaki atau sebaliknya. Oleh karena itu harapan guru dan orang tua, bahwa media literasi berbasis digital ini berada pada titik moderat sehingga dapat diakses baik oleh anak laki-laki maupun perempuan. Kecenderungan persoalan aplikasi digital dengan nuansa gender tertentu lebih pada banyaknya pengembang digital yang memproduksi aplikasi dengan sudut pandang yang sangat maskulin sehingga keterlibatan pandangan perempuan menjadi minim (Fisher \& Jenson, 2017).

Permainan lintas gender dapat diidentifikasi dengan pilihan warna yang netral, misalnya menghindari pemilihan warna pink yang sangat identik dengan warna yang disukai perempuan. Selain pilihan warna, desain grafis yang ada dalam permainan sebaiknya tidak juga memuat desain-desain yang cenderung sangat laki-laki (alat perang) atau sangat perempuan (bunga). Dengan menghindari kecondongan terhadap gender tertentu pada sajian aplikasi, sangat mungkin aplikasi akan lebih cepat diterima oleh anak laki-laki maupun perempuan. Kondisi tersebut tentu akan membuat aplikasi ini digunakan secara lintas gender.

\section{Memuat Aktivitas Bernyanyi}

Literasi awal ditanamkan di TK dengan berbagai nyanyian. Hal ini misalnya dilakukan guru dengan menyanyi saat baris-berbaris sebelum masuk kelas. Sejalan dengan aktivitas guru, orang tua juga sudah memulai aktivitas bernyanyi sejak anak-anak bahkan di dalam 
kandungan. Orang tua biasanya menyenandungkan lagu-lagu daerah untuk pengantar tidur juga untuk menghadirkan suasana tertentu. Singkatnya aktivitas bernyanyi merupakan aktivitas yang dilakukan di sekolah dan di rumah. Berdasarkan hal tersebut maka, media literasi berbasis digital juga semestinya memuat aktivitas bernyanyi. Hal ini karena bernyanyi dapat menumbuhkan perasaan suka cita dan bahagia. Di sisi lain, lagu juga dapat dijadikan sebagai sarana penguatan karakter (Kusumawati, 2013; Rosmiati, 2014).

Menyanyi juga merupakan aktivitas kunci dari fase literasi emergen. Hal ini karena menyanyi merupakan bagian dari penyadaran fonologis dan sekaligus berada dalam dua domain, yaitu Outside-In dan Inside-Out. Outside-In merupakan sarana yang dapat membuat anak mengungkapkan maksud tulisan kepada orang lain dengan pemahaman yang dimilikinya setelah membaca. Selanjut Inside-Out adalah cara mengubah teks yang dibacanya secara lisan atau sebaliknya (Rohde, 2015). Aktivitas bernyanyi ini dapat dipandu dengan video yang disajikan dalam media digital. Video bernyanyi nyatanya memberikan dampak positif pada penguasaan kata anak-anak (Cahyani \& Rasna, 2019). Dengan menggunakan video, anak dapat menirukan lagu. Selain itu, lirik lagu yang ada pada video juga merupakan bentuk dari upaya mendekatkan kegiatan literasi pada anak.

\section{Memuat Aktivitas Menggambar}

Menggambar merupakan aktivitas motorik halus yang sering dilakukan anak. Anak menggambar sesuatu untuk mendeskripsikan apa yang ada dipikirannya. Gambar dapat menjadi sarana ekspresi dari kata atau kalimat yang dipahaminya. Hal inilah yang dilakukan oleh guru di TK. Untuk mengenalkan konsep tertentu, anak diminta menggambar berdasarkan kata yang dikenalnya. Aktivitas ini dapat juga ditambah dengan menceritakan gambar yang sedang dibuatnya. Orang tua juga mengusulkan aktivitas ini, karena anak kadang memiliki cerita yang panjang tentang apa yang digambarkannya. Hal ini sejalan sebuah penelitian yang mengembangkan kemampuan literasi dengan aktivitas menggambar (Pawitri, 2020; Sumitra, Windarsih, Elshap, \& Jumiatin, 2019). Selain itu, menggambar juga sebenarnya dapat meningkatkan kreativitas anak (Wahju, 2020). Kreativitas merupakan aspek penting dalam pertumbuhan anak. Dengan kreativitas anak berlatih agar dapat memecahkan persoalan dirinya. Di sisi lain menggambar juga merupakan sarana pengembangan motorik anak (Sukarini, 2020).

\section{Memuat Aktivitas Bercerita}

Bercerita merupakan aspek penting lainnya dari perkembangan literasi. Memindahkan teks pada buku dalam media digital akan lebih menarik anak. Lebih lagi media tersebut dapat mengeluarkan bunyi-bunyi yang menarik perhatian anak. Hal inilah yang dikemukakan oleh para guru. Cerita yang disampaikan melalui audio visual membuat antusias anak sangat tinggi dibandingkan dengan hanya dibacakan cerita dari sebuah buku (Darihastining, Aini, Maisaroh, \& Mayasari, 2020).

Aktivitas bercerita menurut guru penting disampaikan kepada anak usia dini karena aktivitas ini memungkinkan interaksi antara guru dengan anak. Dalam aktivitas mendongeng anak sering bertanya tentang tokoh maupun jalan cerita yang sedang disampaikan. Anakanak juga kadang menyampaikan hal-hal kritis terkait dengan hal yang dialami oleh tokoh dalam cerita. Ini memberikan ruang untuk kegiatan litarasi pada anak. Hal ini tentu akan baik jika disampaikan orang tua dalam mengisi waktu senggang atau bahkan mengantar anak untuk tidur di malam hari. Dengan demikian, aktivitas bercerita bisa meningkatkan kemampuan berliterasi anak (Sumitra et al., 2019).

Di sisi lain, hadirnya aplikasi dengan cerita beraudio visual tentu akan memudahkan orang tua yang kesulitan dalam mendongeng. Oleh karena itu aktivitas mendongeng bukan menjadi suatu yang sulit dilakukan. Terlebih lagi, penyajian audio visual tentu lebih menarik minat anak dan penelitian pun menunjukkan bahwa media audio visual dapat mengembangkan kemampuan berbahasa anak (Tressyalina, 2020). 
Selain kemampuan bahasa anak yang berkembang, aktivitas bercerita juga sebenarnya merupakan langkah dari pelestarian budaya dengan memperkenalkan cerita-cerita rakyat Indonesia (Puspitasari, Hidayatullah, \& Jupri, 2019). Selain itu, dengan menceritakan cerita rakyat juga sebenarnya anak juga akan belajar tentang kehidupan, antara yang baik dan benar, penjahat dan pahlawan, dan lainnya. Singkatnya, dongeng dapat dijadikan sebagai sarana pembentukkan karakter (Puspitasari, Hidayatullah, \& Jupri, 2018; Suryanto, 2013; Youpika \& Zuchdi, 2016).

\section{Memuat Aktivitas Bermain}

Bermain merupakan aktivitas yang paling digemari oleh anak. Permainan akan dengan mudah membuat anak tertarik. Menurut guru, permainan yang dapat menstimulus kemampuan literasi anak adalah permainan mencocokan kata dengan gambar. Penelitian tentang mencocokkan kata dengan gambar atau sebaliknya sebagai peningkatan kemampuan literasi pernah diteliti. Hasilnya bahwa aktivitas tersebut dapat meningkatkan kemampuan berbahasa anak karena saat bermain anak sedang berupaya mencocokan informasi antara gambar dengan kata yang dikenalnya (Yenni, 2020).

Dengan bentuk aktivitas bermain, maka anak akan belajar sambil bermain. Konsep belajar sambil dan bermain untuk anak usia dini sangatlah cocok. Hal ini karena pada fase perkembangan tersebut anak memang sangat gemar bermain (Kim \& Kim, 2017). Di sisi lain, permainan ini merupakan bentuk dari integrasi antara bermain dan belajar. Pengintegrasian kegiatan keduanya akan berdampak positif pada praktik literasi anak di sekolah maupun di rumah. Hal ini karena anak tidak kesulitan pada aktivitas yang mengintegrasikan antara bermain dan belajar (Pyle, Prioletta, \& Poliszczuk, 2018).

\section{SIMPULAN}

Penelitian ini menunjukkan bahwa guru dan orang tua membutuhkan media digital yang dapat memfasilitasi kegiatan literasi. Hasilnya menunjukkan bahwa media digital tersebut harus dipastikan bebas dari motif gender tertentu sehingga dapat digunakan oleh anak laki-laki dan anak perempuan. Selain itu, permainan ini juga harus memuat aktivitas bernyanyi, menggambar, bercerita, dan bermain. Aktivitas-aktivitas yang sebenarnya memiliki fungsi penting dalam tahap kegiatan pramembaca sebagaimana penelitianpenelitian terdahulu. Oleh karena itu, media literasi berbasis digital sangat mungkin dapat memberikan kesiapan kepada anak untuk berada pada fase terliterasi.

\section{UCAPAN TERIMA KASIH}

Ucapan terima kasih kami sampaikan kepada Sekolah Pascasarjana Universitas Pendidikan Indonesia yang telah memfasilitasi kolaborasi riset terkait dengan topik literasi emergen. Kami juga mengucapkan terima kasih kepada kepala sekolah TK di DKI Jakarta dan Jawa Barat yang telah bersedia memberikan informasi terkait dengan media digital.

\section{DAFTAR PUSTAKA}

Astuti, T. P. (2015). Perbedaan Literasi Emergen Anak Taman Kanak-Kanak Di Daerah Perkotaan Dan Pinggiran. Jurnal Psikologi Undip, 13(2), 107-119. https:// doi.org/10.14710/jpu.13.2.107-119

Borg, W. R., \& Gall, M. D. (1983). Educational Research: An Introduction. New York: Longman. Cahyani, P., \& Rasna, I. wayan. (2019). Pengaruh Media Youtube "Babybus" Terhadap Keterampilan Berbicara Anak 2 Tahun. Jurnal Pendidikan Dan Pembelajaran Bahasa Indonesia, 8(2), 95-102.

Darihastining, S., Aini, S. N., Maisaroh, S., \& Mayasari, D. (2020). Penggunaan Media Audio Visual Berbasis Kearifan Budaya Lokal pada Anak Usia Dini. Jurnal Obsesi: Jurnal Pendidikan Anak Usia Dini, 5(2). https:// doi.org/10.31004/obsesi.v5i2.923 
Fajriyah, L. (2018). Pengembangan Literasi Emergen Pada Anak Usia Dini. Proceedings of the ICECRS, 1(3), 165-172. https:// doi.org/10.21070/ picecrs.v1i3.1394

Fisher, S., \& Jenson, J. (2017). Producing alternative gender orders: a critical look at girls and gaming. Learning, Media and Technology, 42(1), 87-99. https:// doi.org/10.1080/17439884.2016.1132729

Handayani, F. N. (2019). Implementasi gerakan literasi sekolah melalui sudut baca pada anak usia 5-6 tahun di TK Zhafira Keboansikep-Gedangan-Sidoarjo. UIN Sunan Ampel Surabaya.

Hewi, L. (2020). Pengembangan Literasi Anak Melalui Permainan Dadu Literasi Di TK ALAQSHO Konawe Selatan. ThufuLA: Jurnal Inovasi Pendidikan Guru Raudhatul Athfal, 8(1). https:// doi.org/10.21043/thufula.v8i1.7238

Inten, D. N. (2017). Peran Keluarga dalam Menanamkan Literasi Dini pada Anak Role of the FamilyToward Early Literacy of the Children. Golden Age: Jurnal Pendidikan Anak Usia Dini, 1(1), 23-32. https:// doi.org/10.29313/ga.v1i1.2689

Kemendikbud. (2018). Panduan Perjenjangan Buku Nonteks Pelajaran bagi Pelaku Perbukuan. Jakarta: Pusat Perbukuan.

Kim, K., \& Kim, K. (2017). Multimodal play-literacy: a preschooler's storytelling, drawing, and performing of dinosaur extinction theories. Early Child Development and Care, 187(34), 568-582. https:// doi.org/10.1080/03004430.2016.1225044

Kusumawati, H. (2013). Pendidikan karakter melalui lagu anak-anak. Imaji: Jurnal Seni Dan Pendidikan Seni, 11(2). https:// doi.org/10.21831/imaji.v11i2.3839

Li, S., Nan, N., Xu, Q., \& Li, J. (2020). Perceived quality of parent-child relationships by Chinese primary school students: The role of parents' education and parent-child literacy activities. Child Language Teaching and Therapy, 36(2), 79-89. https://doi.org/10.1177/0265659020915943

Miller, J. W., \& McKenna, M. C. (2016). World literacy: How countries rank and why it matters. Routledge. https:// doi.org/10.4324/9781315693934

Pawitri, A. (2020). Peningkatan Kemampuan Menulis Melalui Permainan Menggambar (Penelitian Tindakan di Kelompok B Taman Kanak-kanak Sos Desa Taruna Jakarta Timur). JECIES: Journal of Early Childhood Islamic Education Study, 1(2), 103-122. https://doi.org/10.33853/jecies.v1i2.88

Prioletta, J., \& Pyle, A. (2017). Play and gender in Ontario kindergarten classrooms: implications for literacy learning. International Journal of Early Years Education, 25(4), 393-408. https://doi.org/10.1080/09669760.2017.1390446

Puspitasari, N. A., Hidayatullah, S., \& Jupri, A. R. (2018). Pembentukkan Karakter Anak dengan Menulis Dongeng. In Pesona: Pekan Seminar Nasional Pendidikan Bahasa dan Sastra Indonesia (Vol. 1, pp. 61-66).

Puspitasari, N. A., Hidayatullah, S., \& Jupri, R. (2019). Revitalisasi Sastra Lisan Melalui Pelatihan Media dan Waktu Mendongeng Bagi Orang Tua dan Guru PAUD / TK $\begin{array}{llll}\text { Aisyiah Di Jakarta Selatan. } & \text { Abdinus, 2(2), }\end{array}$ https:// doi.org/10.29407/ja.v2i2.12541

Pyle, A., Prioletta, J., \& Poliszczuk, D. (2018). The Play-Literacy Interface in Full-day Kindergarten Classrooms. Early Childhood Education Journal, 46(1), 117-127. https:// doi.org/10.1007/s10643-017-0852-z

Rohde, L. (2015). The Comprehensive Emergent Literacy Model: Early Literacy in Context. SAGE Open, 5(1), 2158244015577664. https://doi.org/10.1177/2158244015577664

Rosmiati, A. (2014). Teknik Stimulasi dalam Pendidikan Karakter Anak Usia Dini melalui Lirik Lagu Dolanan. Resital: Jurnal Seni Pertunjukan, 15(1), 71-82. https://doi.org/10.24821/resital.v15i1.801

Sidik, U. (2020). Kesesuaian Bahan Bacaan Literasi Emergen dengan Pembaca Sasaran. Widyaparwa, 48(2), 257-268. https:// doi.org/10.26499/wdprw.v48i2.609 
Sukarini, S. (2020). Meningkatkan keterampilan motorik halus melalui kegiatan menggambar dengan teknik finger painting pada anak kelompok B2 di TK Negeri Pembina Bantul. Jurnal Pendidikan Anak, 9(2), 86-93. https://doi.org/10.21831/jpa.v9i2.31355

Sumitra, A., Windarsih, C. A., Elshap, D. S., \& Jumiatin, D. (2019). Meningkatkan Kemampuan Mengenal Huruf Pada Anak Usia Dini Melalui Metode Bercerita Menggunakan Boneka Jari. Tunas Siliwangi : Jurnal Program Studi Pendidikan Guru PAUD STKIP Siliwangi Bandung, 6(1), 1-5.

Suryanto, E. (2013). Model Pendidikan Budi Pekerti Berbasis Cerita Anak untuk Penanaman Nilai Etis-Spiritual. Litera, 12(2). https:// doi.org/10.21831/ltr.v12i02.1581

Tressyalina, T. (2020). Pengembangkan Bahasa Anak Usia Dini Melalui Media Audio Visual di Taman Kanak-kanak Darul Falah. Literasi: Jurnal Bahasa Dan Sastra Indonesia Serta Pembelajarannya, 4(2), 153-157.

Wahju, W. (2020). Upaya Meningkatkan Kreativitas Figural Melalui Kegiatan Menggambar pada Anak Kelompok B TK Dharma Wanita II Kedu Kecamatan Kedu Kabupaten Temanggung Semester II Tahun Pelajaran 2017/2018. Media Penelitian Pendidikan: Jurnal Penelitian Dalam Bidang Pendidikan Dan Pengajaran, 14(2), 186-196. https:// doi.org/10.26877/mpp.v14i2.7700

Yenni, R. P. (2020). Efforts to Improve the Development of Language and Reading Children with the Story and Play Method. SPEKTRUM: Jurnal Pendidikan Luar Sekolah (PLS), 8(2), 182-187.

Youpika, F., \& Zuchdi, D. (2016). Nilai pendidikan karakter cerita rakyat Suku Pasemah Bengkulu dan relevansinya sebagai materi pembelajaran sastra. Jurnal Pendidikan Karakter, (1). https://doi.org/10.21831/jpk.v0i1.10731 